\section{Personlig om hiv}

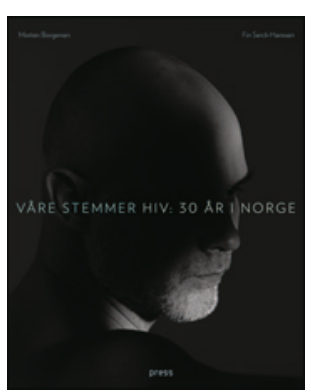

Fin Serck-Hanssen, Morten Borgersen Våre stemmer HIV: $\mathbf{3 0}$ år i Norge 192 s, ill. Oslo: Forlaget Press, 2015. Pris NOK 349 ISBN 978-82-7547-740-6

De første pasientene med alvorlig immunsvikt ble meldt i USA i 1981 og i Norge to år etter; hiv har altså vært med oss i over 30 år. Det anslås at nærmere 80 millioner mennesker er blitt hivsmittet og ca. 40 millioner er døde av hivrelaterte sykdommer. Gjennombruddet for effektiv behandling kom i 1996 og har medført at de fleste med tilgang til moderne medisiner nå kan forvente normal livslengde. Likevel er hivpositive fortsatt en stigmatisert pasientgruppe som ofte opplever ensomhet og isolasjon så vel som smittefrykt og uvitenhet fra omgivelsene.

Boken portretterer og beskriver historien til et bredt utvalg mennesker med tilknytning til hivproblematikken i disse 30 årene; hivpositive, deres familier og sentrale personer fra hjelpeapparatet. Som det fremkommer i innledningen skrevet av initiativtakere til prosjektet, Ole Rysstad, overlege ved Sørlandet sykehus og Kim Fangen, styreleder i Nye Pluss - Hivpositives landsforening, er intensjonen til forfatterne å øke forståelsen for hivpositives livssituasjon og å gi en helsepolitisk vekker.

Vi får presentert 31 personlige historier illustrert med bilder av den enkelte bidragsyter. Språket er lettlest, personlig og direkte, ofte i intervjuform. Den enkelte beskriver sin historie fra diagnose frem til i dag. Her presenteres alle grupper, noe som viser hvor heterogene hivpasienter er: heterofil, homofil, ung og gammel, den etnisk norske som ikke trodde hun kunne bli smittet, den unge jenta født med hiv, rusmisbrukeren, asylsøkeren med krigstraume, men også dem som ikke nådde å få behandling.

Målgruppen er alle typer helsepersonell og studenter, men også andre med interesse for hivpositives livssituasjon. Allmennleger uten spesiell kjennskap til hiv vil kunne ha god nytte av boken for å forstå sine pasienters bakgrunn og reaksjoner bedre. Spesialister som jobber med hiv vil nok kjenne igjen tilsvarende historier fra egne pasienter, men også her vil det være nyttig å lese pasientenes egne opplevelser av hvordan det er å leve med hivdiagnosen.

Enkelte utsagn kan diskuteres i forhold til medisinsk korrekthet. Hivpasienten som føler seg frisk og lever med et avklart forhold til sin sykdom kommer også litt lite til orde. Men leseren får uansett et bredt og godt innblikk i den personlige opplevelsen av hivsykdommen. Boken beskriver en reise gjennom 30 år med hiv i samfunnet samtidig som den påpeker noen av de utfordringene vi fortsatt står overfor i hivomsorgen i dag, ikke minst globalt og i en tid hvor mange banker på Norges dør. Sett i lys av dette er den nyttig og tidsriktig lesing for mange grupper.

Anne Ma Dyrhol Riise

Seksjonsoverlege, Infeksjonsmedisinsk avdeling Oslo universitetssykehus

\section{Sosialantropologisk suksess - fra festning til fruktkompott}

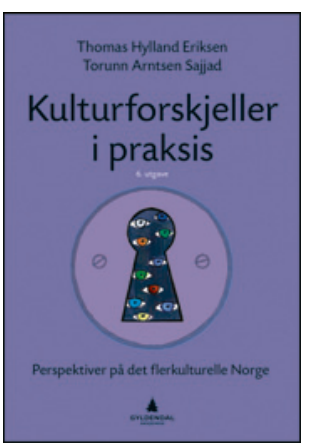

Thomas Hylland Eriksen

Torunn Arntsen Sajjad

Kulturforskjeller i praksis

Perspektiver på det flerkulturelle Norge.

6. utg. 283 s, ill. Oslo: Gyldendal Akademisk,

2015. Pris NOK 465

ISBN 978-82-05-48177-0

Den rappkjeftede Thomas Hylland Eriksen (1962 - ) må vel sies allerede å ha oppnådd ikonstatus sin unge alder til tross. Tilfeldig neppe! Da første utgave av denne boken forelå i 1994, var han bare 32 år, og dette er 6 . utgave siden da. Ikke mange fagbokforfattere kan måle seg med det. Sammen med medforfatter Torunn Arntsen Sajjad har han dessuten også revidert boken fire ganger på disse 20 årene.

Siden jeg ikke kjente boken fra før, og dessuten opplever Hylland Eriksen som vel ordrik, gikk jeg løs på den uten større entusiasme. Men selv om boken klart avspeiler forfatterens muntlige stil, fenget den fra første side, og de aller fleste ordene viser seg å være både viktige og nødvendige. Del 1 er en relativt teoretisk innføring i kulturforståelse og kulturforskjeller, mens andre del inneholder et mylder av eksempler på fleretniske og flerkulturelle situasjoner i Norge. Fra første del vil jeg særlig fremheve kapitlet om menneskerettigheter og det flerkulturelle dilemmaet - tankevekkende! For meg ble eksemplene i del 2 noen ganger vel spesielle og detaljerte, men jeg kan godt tenke meg at lesere som selv er aktører i flerkulturelle settinger kan ha glede og nytte av å lese dette.

Et spørsmål dukker opp underveis: Hvorfor har den sosiale og politiske utviklingen mot større individuell frihet som vi har opplevd i Norge gjennom de siste generasjonene, for eksempel bort fra et patriarkalsk familiemønster eller et tabubelagt seksualliv, gått så mye raskere enn det som beskrives fra innvandrernes hjemland? Finnes det $\mathrm{i}$ det hele tatt en slik utvikling for eksempel i Pakistan? Kanskje kunne forfatterne i neste utgave supplere noen av kapitlene med litt informasjon om dette, for om mulig å gi litt fremtidshåp? De har jo allerede en «observasjonstid» på 20 år.

Tidlig i boken lærer vi at det finnes tre former for kulturblanding: segregering, integrering og assimilering. I avslutningskapitlet Fremtidsutsikter illustrerer forfatterne dette med seks scenarier, der det mest restriktive er festningsscenariet med fullstendig stengte porter og det mest radikale er fruktkompottscenariet, der alt blandes til en grøt, en «kreolisert eller hybridisert kultur hvor kulturelle elementer med forskjellig opprinnelse er blandet sammen, men hvor det ikke er klare grenser mellom gruppene eller kulturene.» Men ønsker vi en slik kompott?

Olaf Gjerløw Aasland

Seniorforsker, Legeforskningsinstituttet 